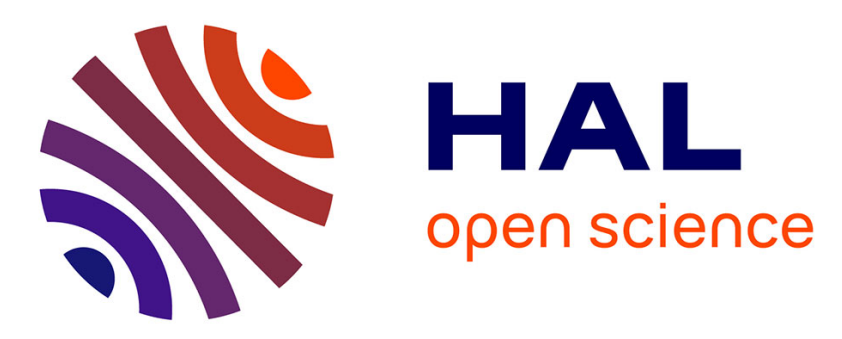

\title{
Peer interaction and problem solving: One example of a logical-discursive analysis of a process of joint decision making
}

\author{
Alain Trognon, Christine Sorsana, Martine Batt, Dominique Longin
}

\section{To cite this version:}

Alain Trognon, Christine Sorsana, Martine Batt, Dominique Longin. Peer interaction and problem solving: One example of a logical-discursive analysis of a process of joint decision making. European Journal of Developmental Psychology, 2008, 5 (5: Developmental Co-construction of Cognition), pp.623-643. 10.1080/17405620701860165 . hal-03478093

\section{HAL Id: hal-03478093 https://hal.science/hal-03478093}

Submitted on 13 Dec 2021

HAL is a multi-disciplinary open access archive for the deposit and dissemination of scientific research documents, whether they are published or not. The documents may come from teaching and research institutions in France or abroad, or from public or private research centers.
L'archive ouverte pluridisciplinaire HAL, est destinée au dépôt et à la diffusion de documents scientifiques de niveau recherche, publiés ou non, émanant des établissements d'enseignement et de recherche français ou étrangers, des laboratoires publics ou privés. 


\title{
Peer interaction and problem solving: one example of a logical-discursive analysis of a process of joint decision making ${ }^{1}$
}

\author{
*University of Nancy 2, France \\ **University of Toulouse 2 \& University of Nancy 2, France \\ ***IRIT, University of Toulouse 1, France
}

Alain Trognon*, Christine Sorsana**, Martine Batt*, \& Dominique Longin***

\begin{abstract}
This article proposes an analysis of a dialogue between two children solving the Tower of Hanoï problem. To carry out such an analysis, we use the Interlocutory Logic which is a formal system constructed to express the logical and phenomenological properties of natural conversation.
\end{abstract}

$\underline{\text { Key words: }}$ peer interaction, problem solving, conversation, Interlocutory Logic.

More and more studies show that when children are confronted with a problem to resolve (e.g. a school evaluation, a psychological test, etc.) their responses depend, among other things, on their conversational interpretation of the questions asked by the adult and, therefore, of the goals this adult assigns to illocutions (Bernicot \& Trognon, 2002; Perret-Clermont, Schubauer-Leoni \& Trognon, 1992; Politzer, 1993; Siegal, 1991). For example, studies have shown that the administering of Piagetian tests runs counter to certain general pragmatic principles that perplex the child and conceal his true skills (Light, Gorsuch, \& Newman, 1987; Light \& Perret-Clermont, 1989; McGarrigle \& Donaldson, 1975). In other words, children, and more generally any cognitive subject, are not "monads." They interact permanently with their environment and in particular with other subjects, including the experimenter thereby entering into a full dialogue (Perret-Clermont, Schubauer-Leoni \& Trognon, 1992). "Accounting for this interaction, and especially for the verbal interaction, which is probably the most elaborate, constitutes an essential challenge for cognitive psychology" (Caron, 1997, p. 234). In addition, contrary to adult/child asymmetrical interactions, interactions between peers - when they do not introduce any initial asymmetry - appear to be an privileged place for understanding the meaning of the task that the child progressively constructs (Grossen, 1994).

\footnotetext{
${ }^{1}$ This article comes from work carried out within a workshop coordinated by Sorsana and Trognon at the University of Nancy 2 (during 2002, 2003 \& 2004) and entitled "Analytic methodological constraints of the cognitive production of a conversation". This workshop was subsidized by the Scientific Counsel of the University of Nancy 2 as well as by the "Psychology of interaction- GRC" laboratory (EA 1129) of the same university.
} 
The studies of the interpersonal forms of learning, initiated by Doise, Mugny and Perret-Clermont (1975), led to propose a psychosocial model of cognition development (see also Doise \& Mugny, 1997; Mugny, 1991; Perret-Clermont, 1996). This is the structuralist model of socio-cognitive conflict. It accounts for the fact that, under certain conditions, working in pairs produces individual cognitive progress greater than that of an individual working alone. "Something" happens therefore in the interpersonal interaction which could provide the beginning of an empirical model of Vygotsky's (1962) idea. According to whom the construction of new interpersonal coordination is accomplished thanks to the internalization of interpersonal coordination. The analysis of researchers of the procedural approach enabled the characterisation of this "interpersonal coordination" hypothesis in describing the actions that are effectively carried out by the partners working together (Gilly, 1990, 1991, 1995; Blaye, 1989, 2001; Dalzon, 2001; Zhou, 2001; Gilly \& Roux, 1988; Roux $\&$ Gilly, 2001). They have shown that the separate actions of the protagonists organize themselves into procedural sequences of resolution. In other words, "they coordinate themselves to become a sequential cognitive procedure," (Gilly, 1989, p. 497). Thus, in certain conditions, children can go beyond interdependence (Deutch, 1949, 1962) arising from reciprocal control of actions whilst developing a collective intentionality (Dascal, 1992; Searle, 1991).

A new step in the knowledge of the role of interactions in acquisition was made when researchers became attentive to utterances considered also as actions besides the resolution processes of those interacting (Perret-Clermont, Schubauer-Leoni \& Trognon, 1992; Trognon, 1992). The objective of contemporary analysis is to identify the conversational "materials" that denote (even constitute) knowledge building operations (Gilly, Roux \& Trognon, 1999; Trognon \& Batt, 2003; Trognon, Batt, Schwarz, Perret-Clermont \& Marro, 2003). This identification is made on the basis of a formal system - the interlocutory logic - conceived to express the logical properties of natural conversation, whilst respecting its phenomenological properties (Trognon, 1999, 2001, 2003; Trognon \& Batt, 2003, 2004, 2007a, 2007b; Trognon, Batt, Schwarz, Perret-Clermont \& Marro, 2006); Trognon \& Coulon, 2001; Trognon \& Kostulski, 1999). The interlocutory logic theory thus proposes an analysis of the socio-cognitive production of a conversation. Analyses that made explicit the emergence of diverse knowledge in interactions, taking place within the framework of interlocutory logic, were published in the last few years. These include the following: (1) knowledge pertaining to the correct placement of a cursor during a word processing tutorial (Trognon \& Saint-Dizier, 1999); (2) knowledge pertaining to the handling of a pneumatic drill during learning in the context of an alternance vocational training system (Sannino, Trognon, Dessagne \& Kostulski, 2001; Sannino, Trognon \& Dessagne, 2003); (3) during liquid conservation tasks (Marro, Trognon \& Perret-Clermont, 1999); (4) during educational learning: number division (Trognon, Saint-Dizier de 
Almeida \& Grossen, 1999) and proportionality (Trognon, Batt, Schwarz, Perret-Clermont \& Marro, 2003, 2006); (5) during hypothetical deductive reasoning applied to an empirical problem (Trognon $\&$ Batt, 2003), to a logic problem (Trognon \& Batt, 2004) or to a diagnostic procedure (Brixhe, Saint-Dizier \& Trognon, 2000). After presenting interlocutory logic, the present study examines the co-resolution of the Hanoï Tower problem by two children.

\section{INTERLOCUTORY LOGIC}

Interlocutory logic is a theory of the logical form of interlocutory events as they occur phenomenologically. That is to say, as they occur with natural language whose sequential production is distributed between several interlocutors (Trognon \& Batt, 2007c; Trognon, Batt \& Laux, 2006). As a formal theory, it constitutes a system of logical methods selected for their capacity to reflect the phenomenological property of the interlocution. Thus, for example, interlocutory logic will resort preferentially to dialogical methods and to natural deduction methods or those derived from them, like the sequent method $^{2}$. The ambition of interlocutory logic is to provide a natural logic of the usage of speech in interaction.

\section{Interlocutory logic is a theory of dialogue movement in its context}

More technically, to analyze an interlocution fragment in interlocutory logic amounts to decomposing this fragment into a series of utterances. Each utterance is represented by an expression $\phi$ of the system: $<\mathrm{M}_{\mathrm{i}},\left\{\mathrm{M}_{\mathrm{i}-\mathrm{k}}\right\},\left\{\mathrm{M}_{\mathrm{i}-\mathrm{k}}\right\} \vdash \mathrm{M}_{\mathrm{i}}, \mathrm{RD}, \mathrm{DG}>$.

$\mathrm{M}_{\mathrm{i}}$ is the conversational move accomplished by the utterance under examination. $\left\{\mathrm{M}_{\mathrm{i}-\mathrm{k}}\right\}$ is the set of all the conversational moves that precede the move $M_{i}$ and from which $M_{i}$ follows. $M_{i}$ can then be conceived as a conclusion that results from premises $\left\{\mathrm{M}_{\mathrm{i}-\mathrm{k}}\right\}$. The reasoning that leads from $\left\{\mathrm{M}_{\mathrm{i}-\mathrm{k}}\right\}$ to $\mathrm{M}_{\mathrm{i}}$, and that is represented by the schema $\left\{\mathrm{M}_{\mathrm{i}-\mathrm{k}}\right\} \vdash-\mathrm{M}_{\mathrm{i}}$, is called, in logic, a sequent ${ }^{3}$.

Let's specify this notion more precisely by adapting an analysis proposed by Carlson (1983) ${ }^{4}$. Suppose that A goes to the stadium to attend a pole-vaulting final between Jack and Bob. Delayed, he only arrives at the stadium once the competition has finished. When arriving A entertains the following "ideas": If someone won it is Jack or Bob and someone has won. Moreover, he asks himself "Who has won?" Catching the sight of his friend B, he engages in the following dialogue:

\footnotetext{
${ }^{2}$ A very accessible presentation of these methods can be found in Vernant (2001).

3 "a sequent" is a pair (note $\Gamma+F$ ) where:

- $\Gamma$ is a finite set of formulas. $\Gamma$ represents the hypotheses that one can use. This set is also called the sequent context

- $F$ is a formula. It is the formula that one wants to demonstrate. This formula is said to be the conclusion of the "sequent" (David, Nour, \& Raffali, 2003, p. 24).

${ }^{4}$ Even in his recent publications (1996, for example) Carlson does not refer to the logic theory of sequents. We think nevertheless that his theory calls for this extension.
} 
1A : Has Jack won?

2B $\quad:$ No

3A : Then Bob won

4B : No

5A : But then nobody won!

(2) is a response to (1). The rule (or rules) (RD) of dialogue (DG) allowing to derive (2) from (1) is represented by the sequent $\{1 \mathrm{~A}\} \vdash 2 \mathrm{~B}$. The rules that lead from the premise to the conclusion are the questioned rules of semantics exposed in the research of Hintikka $(1976,1984,1994)$ of whom Carlson is a student. (3) comes from the "thoughts" entertained by $\mathrm{A}^{5}$ and from the information $2 \mathrm{~B}$ worked out together by the logic rule of the disjunctive dilemma ${ }^{6}$ (5) is again deduced from the thoughts entertained by $\mathrm{A}$ and from $4 \mathrm{~B}$ in using reductio ad absurdum.

In a relatively informal yet sufficient manner for understanding the meaning of our approach, the previous short dialogue has just been reproduced as the product of a set of dialogue rules formulated as sequents. Some of these rules belong to (dialogical forms of) standard logic. This is the case with the disjunctive dilemma or the classic reductio ad absurdum rule which would be used to demonstrate 5A. Other rules concern, instead, the semantics and pragmatics of natural language. We call sequents of dialogue the setting of the relationship in a set of dialogical events (Trognon \& Batt, 2007c; Trognon, Batt, Schwarz, Perret-Clermont \& Marro, 2006). This relationship is an inference composed on the one hand from a set of premises given in the dialogue and, on the other hand, of events which are deduced from these premises. The rules intervening in this inference are rules of a dialogue game. For example, the dialogue sequent $\{1 \mathrm{~A}\}-2 \mathrm{~B}$ rests on a rule belonging to the game theory of the question-response dialogue. This example shows that interlocutory logic seems to generalize the sequent notion to all the illocutory acts used in an interlocution.

\section{The internal composition of the movement of a dialogue}

From the viewpoint of its internal composition, a move $M_{i}$ is an expression of the system ${ }^{7}:<\mathrm{F}(\mathrm{P})$ $>$. $F$ is the force of the speech act accomplished by the uttering the utterance. $F=<f_{1}, f_{2}, f_{3}, f_{4}>$. $f_{1}$ is the force literally expressed, $f_{2}$ the indirect force of the act (if it occurs), $f_{3}$ the implicatures of the act, and $\mathrm{f}_{4}$ the conversational function of the act ${ }^{8}$ We anticipate a little bit the interlocutory analysis

\footnotetext{
${ }^{5}$ This is the cognitive environment of A defined by Sperber and Wilson (1995).

${ }_{7}^{6} \mathrm{p}$ v q, or $\sim$ p, so q.

${ }^{7}$ Interlocutory logic integrates general semantics (Searle \& Vanderveken, 1985; Vanderveken, 1990) as one of its most fundamental components.

${ }^{8} \mathrm{f}_{2}, \mathrm{f}_{3}, \mathrm{f}_{4}$ are not given simultaneously in the discourse. They result from a process of sharing the inter-comprehension which transforms the "meaning of the locutor" into the "interlocutors' meaning" (Clark, 1996, 1999), according to a
} 
which will follow, but let us consider, for example, the utterance $12 \mathrm{Au}$ that has been emitted by Audrey while she is interacting with Vanessa:

\section{Au: on the brown (disc b)}

This elliptic utterance (in fact, it is only a Prepositional Group) is literally an assertive and, non literally, a directive as well as a commissive speech act (because a commissive act is a directive act that the speaker aims at himself). Its conversational function in the interlocution within a framework of problem resolution is 1) to make a proposal for a joint action and 2) in consequence, to refuse the joint action suggested by Vanessa in the preceding speech turn.

$\mathrm{P}$ is the propositional content of the speech act that realises the move Mi. This propositional content is described by expressions of the quantified modal first-order predicate logic ${ }^{9}$. For example, the propositional content of $12 \mathrm{Au}$ is the modal expression presented below which describes a future action of the children.

12Au: $\mathrm{E}_{\mathrm{a}}\left\{\left[\right.\right.$ shall $\left.\left.\mathrm{E}_{\mathrm{v}+\mathrm{a}}(\mathrm{Awb})\right]\right\}$

$\mathrm{E}_{\mathrm{a}}$ : means the (E) action achieved by Audrey (a). The propositional content of this action: [shall $\left.\mathrm{E}_{\mathrm{v}+\mathrm{a}}(\mathrm{Awb})\right]$, with the Awb formula which means white disc on brown disc on peg $A$, is describing a state of the world (Awb) which would be realized in the future ('shall' is the modal marker of the future) by the joint action of the two girls, Vanessa and Audrey $\left(\mathrm{E}_{\mathrm{v}+\mathrm{a}}\right)$.

A simplified way to write the propositional content of this action is (Awb) if we identify Audrey's proposal with the goal that she aims at when she is uttering «on the peg A white on brown». Moreover, because (Awb) $\supset \neg(\mathrm{Bwp})$ is likely to be a mutual knowledge between the two girls, with the Bwp formula which means white disc on pink disc on peg $B$, consequently the (Awb) proposal amounts to declining (Bwp) which is Vanessa's proposal.

In the calculations of interlocutory logic, the forces of speech acts are processed as modalities. An utterance like $12 \mathrm{Au}$ will therefore be written: Directive (Awb). If we assume that the laws of General Semantics (Vanderveken, 1990) belong to the speakers'mutual knowledge while they talk

process described in Trognon (2003), Trognon \& Brassac (1992), Trognon \& Saint Dizier (1999). The formula that describes, in interlocutory logic, the different levels (from the utterance to the direct act, from the direct act to the indirect act, from the indirect act to the conversational move) of the interpretative genesis of the sign-for-interlocutors is borrowed from Jones (1983). For more detail see Trognon \& Batt (2007b), Trognon, Batt \& Laux (2006).

9 "Quantified modal first-order predicate logic" was amended, as suggested by Hintikka, in order to adapt it to the " natural logic of the discourse ». The connectors of interlocutory logic are the connectors of Hintikka's semantic games (Hintikka et Kulas, 1983). But presentation of this complication is unnecessary in the present study. 
together, then the logical expression Directive (Awb) $\supset$ To Desire (Awb) belongs to the speakers'mutual knowledge too, as well as the To Desire (Awb) propositional attitude, thanks to Modus Ponens. As a result, the partners both gain access to (at least) one world $w_{a v}$ in which Vanessa's desire is satisfied, that is to say a world in which (Awb) is true. In this case, $w_{a v}$ is just the content of Audrey and Vanessa's mutual desire. It's an alternative of the real world $w_{0}$, which is the world in which Audrey and Vanessa desire (Awb). The expressions of $w_{a v}$ are therefore the expressions of $w_{0}$ relieved of their modalities. In interlocutory logic, an expression of this kind is called a formula reduced to the propositional content of the speech act. This reduction, legitimate when the dialogue is entirely cooperative, allows the analysis to focus on the dialogue's conceptual content.

\section{THE SOLVING OF THE TOWER OF HANOÏ PROBLEM BY CHILDREN}

\section{Anticipation and planning abilities in children}

Research on children solving the Hanoï Tower problem does not provide consistent results. According to Byrnes and Spitz (1979), planning appears to be very rare before 7-8 years old and only becomes widespread from 14 years old upwards. The problem with two discs is achieved by almost all the subjects as early as 8 years old. The problem with three discs is only successfully solved with the minimum number of moves by $70 \%$ of adolescents aged 14 and over. There is rapid progress between 7 and 9 years old, a plateau between 9 and 12, again important progress between 12 and 14 and, once again, a plateau. These results are in accordance with the different resolution stages reported by Piaget (1974) who placed children in front of an increasing number of discs to move.

This line of research was resumed and disputed by Klahr (1976) and Klahr and Robinson (1981). Using problems with gradual increases in difficulty, the authors showed that children of 5-6 years old presented rudimentary forms of recursive type planning. This planning involved the working out of goals, the detection of obstacles that would prevent the realization of these goals and the detection of rules indicating the conduct to adopt in this case. These subjects would not develop only trial and error behaviour but a more sophisticated attitude with non-random choices.

Richard (1982) studied the forms of action organisation present in the solving of the three discs problem with 495 children aged 7 (tested individually). The following are the principal results:

The frequency of the correct choices increases when children approach the goal, but there is a lack of continuity. A significant proportion of children (.42 in the first attempt; .31 in the second) do not reach the goal and a minimal proportion of children 
attain it with the minimum number of moves $(.06$ in the first attempt; .16 in the second). Even in subjects who do not reach the goal in seven moves, the first move (a deciding factor for the remainder of the problem) does not seem to be the object of any planning that would aim to liberate the larger disc as well as position $\mathrm{C}$ in order to be able to move disc 1 onto it.

- Interruptions are observed in the research behaviour (stopping, attempted illegal moves, steps backwards) and these typically happen at certain positions: $55 \%$ of the subjects have at least two experimenter interventions in the first attempt for violation of the instructions or stopping completely, and $26 \%$ in the second attempt.

- $\quad$ There is a series of positions, of which the preceding ones are a subset where subjects systematically avoid making correct choices. It all happens as if, for them, it was about overcoming a series of obstacles.

Consequently, for Richard (1982), planning $^{10}$ intercedes only in a rather late stage of the resolution and corresponds to a transformation of the problem representation. This transformation is motivated by the failure of rules elicited by early problem representations and results in taking into account crucial aspects of the situation that were neglected up till then.

Richard and Poitrenaud (1988; see also Richard, 1990; 1991) subsequently proposed a modelling of this problem solving. It represents research processes that are missing planning, in the strictest sense of the word. These research processes appear to be, according to the authors, characteristic of new situations where it is not possible to find an analogical situation in memory that could serve as a reference point. The authors define three processes:

1) The representation state, expressed in the form of hierarchical constraints that are, either real constraints of the situation or are imagined by the subject (inappropriate interpretation of the instructions and procedures, goals, rules of action that result).

2) The construction processes of the state of representation corresponding:

a. To the memorisation rules

b. To the production rules of the goals

3) The third process corresponds to the action and control rules.

\section{The solving of the Hanoï Tower problem in dyadic situations}

\footnotetext{
${ }^{10}$ For Richard (1988), planning, in the strictest sense of the word, occurs: either "when the actions necessary to satisfy the instructions can be calculated by action calculation rules but when their execution must be delayed because other constraints must be taken into account to determine the actions' sequential layout"; or "when the situation and the knowledge about the actions is such that other action calculation rules are required to satisfy the task demands" (p. 35). He describes different forms of planning.
} 
Glachan and Light (1982) (and Light \& Glachan, 1985) used wooden material, including discs with handles, while Light, Foot, Colbourn and McClelland (1987) (and Light \& Foot, 1987) programmed this task on a computer. These studies were aimed at children aged 7 to 9 years old and included the same experimental paradigm (pre-test/training /post-test).

The results, with the wooden material, showed that the "dyadic" condition, with participants of similar initial skills, produces significantly better results than the "individual" condition. Nevertheless, the high-performing dyads are the ones that have children who had shown a strategic approach during the pre-test. A closer examination of the possible causes of observed dyadic results showed that regardless of the type of material, only the interactional modality that forced the children to move the discs together produced significant improvements in the post-test. Performance in two other modalities, one where children are not told to move the discs together and another where the experimenter guides each dyad about the optimal sequence for placement without explanation or justification, was significantly lower. In any case, when children used the "computer" version in the same manner as the wooden one, the peer facilitator effect was less prominent than with the wooden material.

\section{INTERLOCUTORY LOGIC OF A SEQUENCE OF CO-RESOLUTION}

The conversational sequence from which the logic form will be constructed is taken from a recording of a dyad of children who are in the process of solving the Hanoï Tower problem with four discs ( $c f$. figure 1).

\section{[INSERT FIGURE 1 HERE]}

This dyad, of Vanessa and Audrey, comes from a sample of 44 dyads of children aged 6 to 8 participating in research whose objective was to study the effect of the quality of children's relationship on their cognitive performance. More precisely, it was to study how some noncognitive determinants, here the affinity ${ }^{11}$, shape particular behaviours that could result in a specific form of cognitive management at the point at which the Hanoï Tower problem, with four discs, is solved (Sorsana, 1996, 1997, 1999; Sorsana \& Musiol, 2005). The experimental apparatus is standard: pre-test (towers with three discs)/ social interaction (with two attempts of co-resolution with four discs) /post-tests (towers with three and four discs). To coerce the children into interacting, the discs were made heavier and they were equipped with handles. Furthermore, the

\footnotetext{
${ }^{11}$ Through the use of a sociometric questionnaire, aimed at children, and a standardized interview with the teachers, we selected pairs of children that appreciated each other (that we called "affinity" pairs in reference to the work of Maisonneuve, 1966) and pairs of children that did not appreciate each other (called "no affinity" pairs).
} 
instructions given demand that every disc is moved together and stipulates "Be careful: to move the discs well it is necessary that you look for the solution together, talk it over together and reach an agreement."

The comparison of the "affinity" and "no affinity" dyads, for the second attempt only, showed a difference in performance and duration of the task depending on the type of dyad: the "affinity" dyads performed better than the "no affinity" dyads $(\mathrm{z}=-2,424, \mathrm{p}=.007)$ and are quicker $(\mathrm{z}=$ $1,908, p=.02)$. In the post-test with four discs, there is a significant difference between the subjects performances, in favour of the "affinity" subjects $(z=-1,652, p=.04)$ with similar task durations $(z$ $=-1,393, p=.08)$. In the post-test with three discs, the differences are not significant.

Only three dyads succeeded in one of the two attempts to rebuild the tower with four discs using the minimum number of moves (i.e. 15). The Vanessa/Audrey dyad was one of them. In addition, the children that were part of this dyad appreciated each other (i.e. it was an "affinity" dyad). The first attempt was accomplished in 35 moves and in 661 seconds. The second attempt was accomplished with an optimum score (15 moves) in 122 seconds. Initially, these two subjects had failed the pretest (i.e. the reconstruction of the tower with three discs). In the post-test with 4 discs, Vanessa rebuilt the tower in 16 moves and 60 seconds; Audrey in 24 moves and 120 seconds. In the post-test with 3 discs, Vanessa accomplished an optimum score (7 moves) in 60 seconds and Audrey, 9 moves in 60 seconds also. For the children in this dyad, interaction will obviously have been beneficial on the cognitive level.

The choice of this sequence is motivated by the examination of the interlocutory processes employed in order to resolve contradictions that are unavoidably generated by the achievement of a collective intentionality. These contradictions present themselves as socio-cognitive conflicts (cf. Doise \& Mugny, 1997; Doise, Mugny \& Perret-Clermont, 1975; Gilly, 1990, 1991, 1995; Mugny, 1991; Perret-Clermont, 1996). These conflicts are, one the one hand, cognitive conflicts: the children's strategies are contradictory; they share the same goal, but can disagree on how to attain it (i.e. on the sequencing of the sub-goals that the task seems to impose on them). These conflicts are also, on the other hand, social, perhaps even emotional, conflicts. The one who wins over the argument in a conflict of responses occurring within a close relationship undermines their partner's face. Consequently they endure the dissonance of infringing upon friendship obligations in wanting the dyad to succeed. The interactional "cost" of a socio-cognitive conflict seems then higher within an affinity dyad than within a dyad with no affinity ${ }^{12}$.

\footnotetext{
${ }^{12}$ In game theories (and in particular dialogue game theory), this factor would play a important role (cf. Bromberg \& Trognon, 2000, 2004; Hintikka, 1962, 1976, 1984).
} 
To study this conflict of responses within the Vanessa/Audrey dyad, we start by reproducing the sequence within which it appears. We then analyze the internal composition of each utterance. Then, we reveal the (dia)logical structure of the utterances that form the socio-cognitive conflict, from its inauguration in the dialogue until its resolution.

\section{Dialogue extract containing the socio-cognitive conflict}

Note: from the smallest one to the biggest one, the colours of the discs of the Tower of Hanoï are: white (w), pink (p), green (g) and brown (b).

1Va: Let's put it (disc w) there (peg B)

2: co-action

3Va: let's put it (disc p) there (peg C)

4: co-action

5Va: after we take the other disc...

6Va: let's put it (disc w) there (peg C)

7: co-action

8Va: let's put it (disc g) there (peg B)

9: co-action

10: (lift up disc w)

11Va: on the green (disc g)

12Au: on the brown (disc b)

13Va1: no

13Va2: on the green

14Au1: no

14Au2: let's put the pink one there (disc p)

15Va1: wait, wait

15Va2: (looks at the experimenter)

15Va3: let's put it on the green

16Au1: no

16Au2: afterwards let's put that one there (disc $\mathrm{p}$ on disc $\mathrm{g}$ using her hand gesture)

17Va1: yes

17Va2: but we must build the tower there (peg C)

17Va3: ah yes

17Va4: that's it

18: co-action (disc w) on disc b on peg A)

19: co-action (disc $\mathrm{p}$ on disc $\mathrm{g}$ on peg $\mathrm{B}$ )

20Va: OK!

21Au: (smiles)

\section{Internal decomposition of the series of dialogue moves contributing to the socio-cognitive conflict}

Our analysis concerns the extract $(11 \mathrm{Va} . .21 \mathrm{Au})$ that is produced immediately following the lifting up of disc 1 (w) by the two children. This sequence sets the stage for a disagreement between the two children. From this disagreement an inter-comprehension process emerged that then leads to an agreement. Even though, from $11 \mathrm{Va}$ to $15 \mathrm{Va}$, the disagreement is concerned with the place where 
to put (w), it is Audrey's reasoning, in $14 \mathrm{Au}$ and $16 \mathrm{Au}$, that ends up imposing itself as illustrated by what Vanessa expresses in 17Va.

Once the 9 co-action is carried out, the four discs arise on the pegs as follows: the brown disc is on peg $\mathrm{A}$, so we write $[\mathrm{A}(-,-,-, \mathrm{b})]$, the green disc is on peg $\mathrm{B}$, so we write $[\mathrm{B}(-,-,-, \mathrm{g})]$ and the white and pink discs are on peg $\mathrm{C}$, so we write $[\mathrm{C}(-,-, \mathrm{w}, \mathrm{p})]$. When several discs are on the same peg, they are written from the smallest one to the biggest one. Thus, the overall configuration of pegs and discs is: $[\mathrm{A}(-,-,,-, \mathrm{b}) \& \mathrm{~B}(-,-,-, \mathrm{g}) \& \mathrm{C}(-,-, \mathrm{w}, \mathrm{p})]$.

The different stages followed by the children until the preceding configuration are as follows:

Initial situation

$1 \mathrm{Va}$ then 2 co-action

$3 \mathrm{Va}$ then 4 co-action

5-6 Va then 7 co-action

8 Va then 9 co-action

$$
\begin{aligned}
& : \mathrm{A}(\mathrm{w}, \mathrm{p}, \mathrm{g}, \mathrm{b}) \& \mathrm{~B}(-,-,-,,-) \& \mathrm{C}(-,-,,-,) \\
& : \mathrm{A}(-, \mathrm{p}, \mathrm{g}, \mathrm{b}) \& \mathrm{~B}(-,-,-, \mathrm{w}) \& \mathrm{C}(-,-,,-,-) \\
& : \mathrm{A}(-,-, \mathrm{g}, \mathrm{b}) \& \mathrm{~B}(-,-,-, \mathrm{w}) \& \mathrm{C}(-,-,-, \mathrm{p}) \\
& : \mathrm{A}(-,,-\mathrm{g}, \mathrm{b}) \& \mathrm{~B}(-,-,-,,-) \& \mathrm{C}(-,-, \mathrm{w}, \mathrm{p}) \\
& : \mathrm{A}(-,,-,-\mathrm{b}) \& \mathrm{~B}(-,-,,-\mathrm{g}) \& \mathrm{C}(-,-, \mathrm{w}, \mathrm{p})
\end{aligned}
$$

The girls progressed as if they were following the exact pattern of the recursive model ${ }^{13}$ of the resolution of the Tower of Hanoï problem. According to this model, "in order to move n discs from peg A to peg $\mathrm{C}$, one must necessary proceed in three stages. The first stage consists in transferring $\mathrm{n}-1$ discs from peg A to peg B, the second stage in transferring one disc (the biggest one) from peg A to peg $\mathrm{C}$ and the last stage in transferring n-1 discs from peg B to peg C" (Gochet, Gribomont \& Thayse, 2000, pp. 262-264). By applying this method n-1 times, "one gets the optimal list of the elementary moves" (p. 264); and it's exactly the way that will be followed by Audrey and Vanessa. The children have two options when they lift up disc w. Either Vanessa and Audrey put it on peg A (on the brown disc): [A(-, -, w, b)]. Either they put it on peg B (on the green disc): [B(-, -, W, g)]. The choice is strategically decisive. The girls have just moved two discs from peg A to peg $\mathrm{C}$ and another disc from peg A to peg B. They are therefore very close to reach an essential sub goal in the solution of the problem: moving three discs from peg A to peg B, then moving a disc from peg A to peg C. Indeed, to reach this state of the world, they only have to proceed from 9 as follows below:

$$
\mathrm{A}(-,-, \mathrm{w}, \mathrm{b}) \& \mathrm{~B}(-,-,-, \mathrm{g}) \& \mathrm{C}(-,-,-, \mathrm{p})
$$

\footnotetext{
${ }^{13}$ The authors hold at the disposal of readers a recursive data-processing model of the children's enacted reasoning.
} 
$\mathrm{A}(-,-, \mathrm{w}, \mathrm{b}) \& \mathrm{~B}(-,-, \mathrm{p}, \mathrm{g}) \& \mathrm{C}(-,-,,-,-)$

$\mathrm{A}(-,-,-, \mathrm{b}) \& \mathrm{~B}(-, \mathrm{w}, \mathrm{p}, \mathrm{g}) \& \mathrm{C}(-,-,-,,-)$

$\mathrm{A}(-,-,-,,-) \& \mathrm{~B}(-, \mathrm{w}, \mathrm{p}, \mathrm{g}) \& \mathrm{C}(-,-,-, \mathrm{b})$

The choice is crucial from two points of view. From a logical standpoint, it is clear that to move the white disc on the green disc (Vanessa's proposal) is less interesting than to move the white disc on the brown disc (Audrey's proposal) because, in the latter proposal, then the pink disc may be moved on the green one, then the white disc on the pink one, and finally the brown disc on peg C. From a psychological standpoint now, in their modelling of the solution of the problem, Richard and Poitrenaud (1988) and Richard (1990, 1991) demonstrate that in this solving stage the participants (including adults) avoid placing another disc on the larger disc - finally released - and favour the movement of disc $\mathrm{w}$ onto the peg B.

From $11 \mathrm{Va}$ to $21 \mathrm{Au}$, the children will find the best solution. But they will have to exceed a sociocognitive conflict before. This conflict develops as follows. From 10 to $13 \mathrm{Va}_{2}$, we attend the installation of the conflict. Each girl states the goal she wants to carry out (11Va versus $12 \mathrm{Au})$, then the incompatibility with the partner's goal $\left(13 \mathrm{Va}_{1}\right.$ versus $\left.14 \mathrm{Au}_{1}\right)$ : the contradiction of the propositional contents involves an incompatibility of the acts (Searle \& Vanderveken, 1985). An argumentative phase follows, more or less superimposed on the preceding phase. During this phase, each player argues her thesis $\left(14 \mathrm{Au}_{2}-16 \mathrm{Au}_{2}\right.$ versus $\left.17 \mathrm{Va}_{2}\right)$. Then, a phase of resolution may close the conflict, like in the interaction that we are examining ( $c f$. table 1), where one of the girls will adopt the option initially suggested by her partner.

[INSERT TABLE 1 HERE]

By calculating her proposal with her partner's proposal taken as an assumption, each girl deduces a contradiction, by a simple reasoning ad absurdum. Because the interaction cannot continue on the mode of opposition, except by entering a "dialogue of the deaf" where each interlocutor indefinitely repeats his point of view, alternatively at each turn of speech, the girls must adopt another dialogue game if they wish to prolong their cooperation. Then they engage in a mixed dialogue of argumentation (Rips, 1998; Walton \& Krabbe, 1995), in which each player is supposed to persuade her partner by using a battery of strategies. To challenge her partner to argue in favour of her own thesis is one of these strategies. A player receiving a challenge must put forward an argument, 
otherwise he loses the game. In this interaction, no challenge is uttered, but the children put forward their arguments respectively. Examining both the justification put forward by Vanessa $\left(17 \mathrm{Va}_{2}\right)$ and the arguments uttered by Audrey in order to reject Vanessa's proposal $\left(16 \mathrm{Au}_{1}+16 \mathrm{Au}_{2}\right)$, we notice that the former follows from the latter:

$\left(16 \mathrm{Au}_{1} \& 16 \mathrm{Au}_{2}\right) \rightarrow 17 \mathrm{Va}_{2}$

The dialogue game theory of persuasion (Walton \& Krabbe, 1995) demonstrates that a player wins the game when he manages to demonstrate his thesis starting from the opponent's concessions. If we supposed that Vanessa took Audrey's assertions for assumptions in her own reasoning, then she should deduce $17 \mathrm{Va}_{2}$. Consequently, Vanessa hasn't got any more reason to reject Audrey's proposal. Moreover, if Audrey's proposal and Vanessa's both lead to the same situation - the release of the peg C - Audrey's proposal remains strategically higher, because it makes it possible to reach a key sub goal of the problem more quickly. And it's subjected to the condition that Vanessa's proposal will be followed by a move of the pink disc on the brown one, proposal which is not uttered by Vanessa (yet?). In any case, the positive relationships between the two girls are likely to support the resolution of the disagreement (17 $\left.\mathrm{Va}_{3-4}\right)$. Therefore they accomplish Audrey's solution (18-19), and Vanessa approves its accuracy (20Va) to Audrey's satisfaction which she expresses with her smiles $(21 \mathrm{Au})$.

In the analysis that we propose here, on the one hand, Vanessa will not have needed to devote herself to a comparative study of the consequences of both her proposal and Audrey's on the rest of the play to adopt her partner's standpoint: the interest of Audrey's proposal is "staring her in the face". On the other hand, the success of Audrey's strategy, that the children will then test, will reinforce their decision positively. It may be thanks to a contingent interaction like the one that we have just examined that Audrey and Vanessa acquired the solution of the Tower of Hanoï problem.

\section{CONCLUSION}


In this article, we showed how interlocutory logic can formalize the socio-cognitive conflict, which is an essential ingredient of development for the psychology of social genetics "school" (Doise \& Mugny, 1997; Doise, Mugny \& Perret-Clermont, 1975; Mugny, 1991; Perret-Clermont, 1996). Until now, interlocutory logic, which is generally meant as a theory on the "logic form" of interlocutions or as a theory of the "natural logic" contained in discourse usage in interaction, has mainly been used to formally demonstrate socio-cognitive events. The interlocutory events in these analyses are taken as conclusions to be inferred in a dialogue system. For example, in the present article, interlocutory logic explains why Vanessa grants Audrey's suggestion whilst abandoning hers. This amounts to solving the socio-cognitive conflict in which the children were involved. This resolution mode differs from the one considered most effective from the standpoint of cognitive development by the social genetic psychology school. Vanessa's agreement is situated, in effect, between the obliging agreement (compliance) and the integration of two viewpoints in a synthesis that preserves them and exceeds them. What remains is that, even though demonstrative, our (dia)logical explanation constitutes speculation among others. It will only be possible to ascertain it by appealing to the "cutting edge" of experimentation.

Compared to the psychosocial theory of the cognitive development, interlocutory logic constitutes a formal improvement because it clarifies the semiotic mediations in which the sequential cognitive procedures are expressed. Interlocutory logic also constitutes a theoretical improvement insofar as the sequential cognitive procedures are rarely given directly in the interaction, that is to say in the "ordinary life" (Trognon, Batt et Laux, 2007; Trognon \& Bromberg, 2008).

Other uses of interlocutory logic are conceivable in developmental psychology. For example: to design a developmental model of interactional competences and their cognitive effects, following up on the works of Bruner (1983, 1986, 1990), Harris (2000) and Tomasello (1999); to better control the situation that constitutes "the uphill struggle" of developmental psychology and all the others; that is, "the indeterminacy of radical translation" (Quine, 1960), of which Piaget was, in his own way, surely acutely aware when he devised the clinical interview (Piaget, 1926). 


\section{REFERENCES}

Bernicot, J., \& Trognon, A. (2002). Le tournant pragmatique en psychologie. In Bernicot, J., Trognon, A., Guidetti, M., Musiol, M. (Eds), Pragmatique et psychologie (pp. 13-32). Nancy: Presses Universitaires de Nancy.

Blaye, A. (1989). Interactions sociales et constructions cognitives: présentation critique de la thèse du conflit sociocognitif. In N. Bednarz, \& C. Garnier (Eds.), Construction des savoirs: obstacles et conflits (pp. 183-194). Montréal: Agence d'Arc inc.

Blaye, A. (2001). Mécanismes générateurs de progrès lors de la résolution à deux d'un produit de deux ensembles par des enfants de 5-6 ans. In A.N. Perret-Clermont, M. Nicolet (Eds.), Interagir et connaître. Enjeux et régulations sociales dans le développement cognitif (pp. 49-62). Paris: L'Harmattan (first edition, 1988).

Brixhe, D., Saint-Dizier, V., \& Trognon, A. (2000). Résolution interlocutoire d'un diagnostic. Psychologie de l'Interaction, 9-10, 211-237.

Bromberg, M. \& Trognon, A. (2000). La psychologie sociale de l'usage du langage. In N. Roussiau (Ed.), Psychologie Sociale (pp. 293-312). Paris: In press Editions.

Bromberg, M., \& Trognon, A. (2004). Introduction. In M. Bromberg \& A. Trognon (Eds.), Psychologie Sociale et Communication (pp.1-15). Paris: Dunod.

Bruner, J. (1983). Child's Talk: Learning to Use Language. New York: Norton.

Bruner, J. (1986). Actual Minds, Possible Worlds. Cambridge, MA: Harvard University Press.

Bruner, J. (1990). Acts of Meaning. Cambridge, MA: Harvard University Press.

Byrnes, M.N., \& Spitz, H.H. (1979). Developmental progression of performance on the Tower of Hanoï problem, Bulletin of the Psychonomic Society, 14 (5), 379-381.

Carlson, L. (1983). Dialogue games. An approach to discourse Analysis. Dordrecht: Reidel.

Carlson, L. (1996). Language as a Game. In J. L. Mey (Ed.), Concise Encyclopedia of Pragmatics (pp. 447-450). Amsterdam: Elsevier.

Caron, J. (1997). Psychologie cognitive et interactions conversationnelles. In Bernicot, J., CaronPargue, J, Trognon, A. (Eds.), Conversation, interaction et fonctionnement cognitif (pp. 221237). Nancy: Presses Universitaires de Nancy.

Clark, H.H. (1996). Using language. Cambridge: Cambridge University Press.

Clark, H.H. (1999). On the origins of conversation. Verbum, XXI, 2, 147-161.

Dalzon, C. (2001). Conflit cognitif et construction de la notion Droite/Gauche. In A.N. PerretClermont, M. Nicolet (Eds.), Interagir et connaître. Enjeux et régulations sociales dans le développement cognitif (pp. 63-78). Paris: L'Harmattan (first edition, 1988).

Dascal, M. (1992). On the pragmatic structure of conversation. In H. Parret, \& J. Verschueren (Eds.), (On) Searle on conversation (pp. 35-57). Amsterdam, Philadelphia: John Benjamins Publishing Company.

David, R., Nour, K. \& Raffalli, C. (2003). Introduction à la logique. Paris: Dunod.

Deutsch, M. (1949). A theory of cooperation and competition. Human Relations, 2, 129-152.

Deutsch, M. (1962). Cooperation and trust: Some theoretical notes. In M. R. Jones (Ed.), Nebraska Symposium on Motivation (pp. 275-320). Lincoln: University of Nebraka Press.

Doise, W., \& Mugny, G. (1997). Le développement social de l'intelligence. Paris: A. Colin (first edition, 1981).

Doise, W., Mugny, G., \& Perret-Clermont, A.N. (1975). Social interaction and the development of cognitive operations, European Journal of Social Psychology, 5, 367-383.

Gilly, M. (1989). Commentaires (du rapport de Jean-Paul Codol « Cognition sociale »). Bulletin de Psychologie, XLII (390), 494-497.

Gilly, M. (1990). Mécanismes psychosociaux des constructions cognitives: perspectives de recherche à l'âge scolaire. In G. Netchine-Grynberg (Ed.), Développement et fonctionnement cognitif: renouveaux en psychologie de l'enfant (pp. 201-222). Paris: Presses Universitaires de France.

Gilly, M. (1991). Social psychology of cognitive constructions: european perspectives. In M. Carretero, M. Pope, S. Robertjan, \& J.L. Pozo (Eds.) Learning and instruction. European Research in an International Context. vol. III (pp. 99-123). Oxford: Pergamon Press. 
Gilly, M. (1995). Approches socioconstructives du développement cognitif. In G. Gaonac'h \& C. Golder (Eds.), Manuel de psychologie pour l'enseignement (pp. 130-167). Paris: Hachette (Education).

Gilly, M., \& Roux, J.-P. (1988). Social marking in ordering tasks: effects and action mechanisms, European Journal of Social Psychology, 18, 251-266.

Gilly, M., Roux, J.-P., \& Trognon, A. (1999) (Eds.), Apprendre dans l'interaction. Analyse des médiations sémiotiques. Aix-en-Provence et Nancy: Presses de l'Université de Provence et Presses Universitaires de Nancy.

Glachan, M., \& Light, P. (1982). Peer interaction and learning: can two wrongs make a right? In G. Butterworth, \& P.Light (Eds.), Social cognition (pp. 238-262). Chicago: University of Chicago Press.

Gochet, P., Gribomont, P., \& Thayse, A. (2000). Logique. Méthodes pour l'intelligence artificielle. Paris: Hermès.

Grossen, M. (1994). Theoretical and methodological consequences of a change in the unit of analysis for the study of peer interactions in a problem solving situation, European Journal of Psychology of Education, $I X(1), 159-173$.

Harris, P. L., (2000). The work of the imagination. Oxford, UK: Blackwell.

Hintikka, J. (1962). Knowledge and Belief. An Introduction to the Logic of the Two Notions. Ithaca, New York: Cornell University Press.

Hintikka, J. (1976). Languages-Games. Acta Philosophica Fennica, 28,1-3 (Essays on Wittgenstein in honour of G. H. Von Wright), 105-125.

Hintikka, J. (1984). Rules, utilities, and strategies in dialogical games. In L. Vaina and J. Hintikka (Eds.), Cognitive Constraints on Communication (pp. 277-294). Amsterdam: D. Reidel Publishing Compagny.

Hintikka, J. (1994). Fondements d'une théorie du langage. Paris: Presses Universitaires de France.

Hintikka, J., \& Kulas, J. (1983). The game of language. Studies in Game Theoretical Semantics and its applications. Dordrecht: D. Reidel.

Jones, Andrew. J. I. (1983). Communication and Meaning. An Essay in Applied Modal Logic. Dordrech, Boston, Lancaster: Reidel.

Klahr, D. (1976). Goal formation, planning and learning by pre-school problem solvers or "my socks are in the dryer". In R.S. Siegler (Ed.), Children's thinking. What develops? (pp. 181212). Erlbaum: Hillsdale.

Klahr, D., \& Robinson, M. (1981). Formal assessment of problem solving and planning processes in preschool children, Cognitive Psychology, 13, 113-148.

Light, P. \& Perret-Clermont, A.-N. (1989). Social context effects in learning and testing. In A. Gellatly, D. Rogers, \& J.A. Sloboda (Eds.), Cognition and Social words (pp. 99-112). Oxford: Science Publications, University Press.

Light, P., \& Foot, T. (1987). Peer interaction and micro-computer use, Rassegna di Psicologia, 4, $\mathrm{n}^{\circ} 2 / 3,93-104$.

Light, P., \& Glachan, M. (1985). Facilitation of individual problem solving through peer interaction, Educational Psychology, 5, 217-225.

Light, P., Foot, T., Colbourn, C., \& Mc Clelland, I. (1987). Collaborative interactions at the microcomputer keyboard, Educational Psychology, 7, 1, 13-21.

Light, P., Gorsuch, C., \& Newman, J. (1987). "Why do you ask?" Context and communication in the conservation task. European Journal of Psychology of Education, II, 1, 73-82.

Maisonneuve, J. (1966). Psycho-sociologie des affinités. Paris: Presses Universitaires de France.

Marro P., Trognon, A. \& Perret-Clermont, A.-N. (1999). Processus interlocutoires dans une tâche de conservation des liquides. In M. Gilly, J. P. Roux \& A. Trognon (Eds.). Apprendre dans l'interaction: Analyse des médiations sémiotiques (pp. 163-180). Aix-en-Provence \& Nancy: Publications de l'Université de Provence \& Presses Universitaires de Nancy.

McGarrigle, J. \& Donaldson, M. (1975). Conservation accidents. Cognition, 3 (4), 341-350.

Mugny, G. (1991). Psychologie sociale du développement cognitif. Berne: P. Lang (first edition, 1985).

Perret-Clermont, A.N. (1996). La construction de l'intelligence dans l'interaction sociale. Berne: P. Lang (first edition, 1979).

Perret-Clermont, A.N., Schubauer-Leoni, M.L., \& Trognon, A. (1992). L'extorsion des réponses en situation asymétrique, Verbum, 1-2, 3-32.

Piaget, J. (1926). La représentation du monde chez l'enfant. Paris: Presses Universitaires de France. Piaget, J. (1974). La prise de conscience. Paris: Presses Universitaires de France. 
Politzer, G. (1993). La psychologie du raisonnement: lois de la pragmatique et logique formelle. Doctorat d'Etat ès Lettres et Sciences Humaines. Université de Paris VIII, Paris.

Quine, W.V.O. (1960). Word and Object. MA: MIT Press

Richard, J.-F. (1982). Planification et organisation des actions dans la résolution du problème de la Tour de Hanoï par des enfants de 7 ans, L'Année Psychologique, 82, 307-336.

Richard, J.-F. (1988). Les activités de planification chez l'enfant, Revue Française de Pédagogie, $82,33-37$.

Richard, J.-F. (1990). Les activités mentales: comprendre, raisonner, trouver des solutions. Paris: A.Colin.

Richard, J.-F. (1991). Analyse de procédures et modélisation de la résolution de problème. In G. Vergnaud (Ed.), Les sciences cognitives en débat (pp. 29-40). Paris: CNRS Editions.

Richard, J.-F. \& Poitrenaud, S. (1988). Problématique de l'analyse des protocoles individuels d'observations comportementales. In J.P. Caverni (Ed.), Psychologie cognitive, modèles et méthodes (pp. 405-426). Grenoble: Presses Universitaires de Grenoble.

Rips, L. J. (1998). Reasoning and Conversation. Psychological Review, 105(3), 411-441.

Roux, J.-P., \& Gilly, M. (2001). Contribution à l'étude des mécanismes d'action du marquage social dans une tâche d'ordination à 12-13 ans. In A.N. Perret-Clermont, \& M. Nicolet (Eds.), Interagir et connaître: Enjeux et régulations sociales dans le développement cognitif (pp. 171-185). Cousset: DelVal (first edition, 1988).

Sannino, A., Trognon, A., Dessagne, L. (2003). A model for analyzing knowledge content and processes of learning a trade within alternance vocational training. In T. Tuomi-Groh \& Y. Engeström (Eds.), Between school and work: new perspectives on transfer and boundarycrossing (pp. 271-289). Amsterdam: Pergamon.

Sannino, A., Trognon, A., Dessagne, L., \& Kostulski, K. (2001). Les connaissances émergeant d'une relation tuteur-apprenti sur le lieu de travail. Bulletin de Psychologie, 54 (3), 453, 261 273.

Searle, J.R., \& Vanderveken, D. (1985). Foundations of illocutionary logic. Cambridge: Cambridge University Press.

Searle, J.R. (1991). On Searle on Conversation. Pragmatics and Beyond. Amsterdam: John Benjamins Publishing Company.

Siegal, M. (1991) A clash of conversational worlds: interpreting cognitive development through communication. In L.B. Resnick, J. M. L. S Teasley (Eds), Perspectives on socially shared cognition, (pp. 23-41). Washington, DC: American Psychological Association.

Sorsana, C. (1996). Relations affinitaires et co-résolution de problème: analyse des interactions entre enfants de six-huit ans. Interaction et Cognitions, 2-3, 263-291.

Sorsana, C. (1997). Affinités enfantines et co-résolution de la Tour de Hanoï. La Revue Internationale de Psychologie Sociale, 1, 51-74.

Sorsana, C. (1999). Stratégies sociocognitives dans la résolution de la Tour de Hanoï. In M. Gilly, J.P. Roux, \& A. Trognon (Eds.), Apprendre dans l'interaction. Analyse des médiations sémiotiques (pp. 143-161). Aix-en-Provence \& Nancy: Presses de l'Université de Provence \& Presses Universitaires de Nancy.

Sorsana, C., \& Musiol, M. (2005). Power and knowledge: how can rationality emerge from children's interactions in a problem-solving situation? In E. Grillo (Ed.), Power Without Domination, Dialogism and the Empowering Property of Communication. (pp. 161-221). Amsterdam: J. Benjamins.

Sperber, D., \& Wilson, D. (1995). Relevance. Communication and cognition. Oxford: Blackwell Publishers Ltd (first edition, 1986).

Tomasello, M. (1999). The cultural origins of human cognition. New York: Harvard University Press.

Trognon, A. (1992). Psychologia cognitiva e analisi delle conversazioni. In C. Galimberti (Ed.), La conversazione. Prospettive sull'interazione psico-sociale (pp. 115-155). Milano: Guerini Studio.

Trognon, A. (1999). Eléments d'analyse interlocutoire. In M. Gilly, J.P. Roux, \& A. Trognon (Eds.), Apprendre dans l'interaction. Analyse des médiations sémiotiques (pp. 69-94). Aix-enProvence \& Nancy: Publications de l'Université de Provence \& PUN.

Trognon, A. (2001). Speech acts and the logic of mutual understanding. In D. Vanderveken \& S. Kubo (Eds.), Essays in speech act theory (pp. 121-133). Amsterdam: J. Benjamins \& Sons. 
Trognon, A. (2003). La Logique Interlocutoire: Un programme pour l'étude empirique des jeux de dialogue. Questions de communication, 4, 411-425.

Trognon, A., \& Batt, M. (2003). L'élaboration et l'appropriation des cognitions dans l'interlocution ou comment représenter le passage de l'Intersubjectif à l'Intrasubjectif en Logique Interlocutoire. L'Orientation Scolaire et Professionnelle, 32, 3, 399-436.

Trognon, A., \& Batt, M. (2004). Logique Interlocutoire des jeux de dialogue: Un programme en Psychologie Sociale de l'usage du langage. In M. Bromberg \& A. Trognon (Eds.), Psychologie Sociale et Communication (pp. 135-156). Paris: Dunod.

Trognon, A., \& Batt, M. (2007a, in press). An unified framework for studying conversational interaction. In P. J. Thibault \& C. Prevignano (Eds.), Interaction Analysis and Language: Discussing the state-of-art. John Benjamins Publishing Company.

Trognon, A., Batt, M. (2007b). Quelles méthodes logiques pour l'étude de l'interaction en psychologie. In C. Chabrol, I. Olry-Louis \& F. Najab (Eds.), Interactions communicatives et psychologies (pp. 53-65). Paris: Presses de la Sorbonne Nouvelle.

Trognon, A., Batt, M. (2007c). Comment conduire l'examen d'un fragment d'interlocution au moyen de la logique interlocutoire. In A. Specogna (Ed.) Enseigner dans l'interaction (pp. 13-33). Nancy: Presses Universitaires de Nancy.

Trognon, A., Batt, M., \& Laux, J. (2006). Logique interlocutoire du problème des quatre cartes posé à une dyade. Psychologie de l'Interaction, 21-22, 143-188.

Trognon, A., Batt, M., \& Laux, J. (2007). Psychologie sociale et raisonnement. In S. Rossi \& J. B. Van der Henst (Eds.), Psychologies du raisonnement (p.141-166). Bruxelles: De Boeck.

Trognon, A., Batt, M., Schwarz, B., Perret-Clermont, A. N., \& Marro, P. (2003). L'apprentissage dans l'interaction: Essai d'analyse interlocutoire. In A. Herzig, B. Chaib-Draa \& P. Mathieu (Eds.), MFI'03 Modèles formels de l'interaction (pp. 229-240). Toulouse: Cépaduès.

Trognon, A., Batt, M., Schwarz, B., Perret-Clermont, A. N., \& Marro, P. (2006). Logique interlocutoire de la résolution en dyade d'un problème d'arithmétique. Psychologie Française, 51, 171-187.

Trognon, A., \& Brassac, C. (1992). L'enchaînement conversationnel. Cahiers de linguistique française, 13, 76-107.

Trognon, A., \& Bromberg, M. (2008). L'interaction sociale. In A. Trognon \& M. Bromberg (Eds.), Psychologie sociale et ressources humaines. Paris: Presses Universitaires de France.

Trognon, A., \& Coulon, D. (2001). La modélisation des raisonnements générés dans les interlocutions. Langages, 144, 58-77.

Trognon, A., \& Kostulski, K. (1999). Eléments d'une théorie sociocognitive de l'interaction conversationnelle. Psychologie Française, 44 (4), 307-318.

Trognon, A., \& Saint-Dizier, V. (1999). L'organisation conversationnelle des malentendus: le cas d'un dialogue tutoriel, Journal of Pragmatics, 31, 787-815.

Trognon, A., Saint-Dizier de Almeida, V. \& Grossen, M. (1999). Résolution conjointe d'un problème arithmétique. In M. Gilly, J. P. Roux \& A. Trognon (Eds.). Apprendre dans l'interaction: Analyse des médiations sémiotiques (pp. 121-141). Aix-en-Provence \& Nancy: Publications de l'Université de Provence \& Presses Universitaires de Nancy.

Vanderveken, D. (1990). Meaning and Speech Acts. Cambridge: Cambridge University Press.

Vernant, D. (2001) Introduction à la logique standard. Paris: Flammarion.

Vygotski, L.S. (1962). Thought and Language. Cambridge: MIT Press.

Walton, D., Krabbe, C. W. (1995). Commitment in Dialogue: Basic Concepts of Interpersonal Reasoning. Albany: State University of New York Press.

Zhou, R.M. (2001). Norme égalitaire, conduites sociales de partage et acquisition de la conservation des quantités. In A.N. Perret-Clermont, \& M. Nicolet (Eds.), Interagir et connaître: Enjeux et régulations sociales dans le développement cognitif (pp. 187-201). Paris: L'Harmattan (first edition, 1988).

Authors'note: We would like to thank Ciarán O'Keeffe and Maryse Noté for their help to the translation into English. 


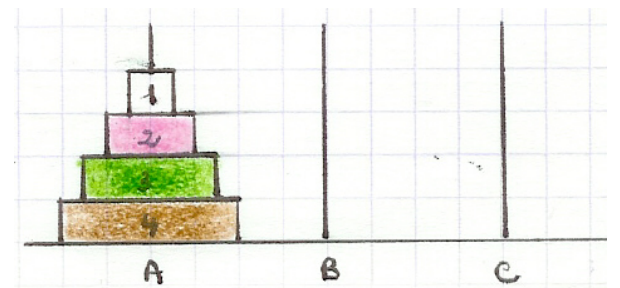

Figure 1. The Tower of Hanoï problem with four discs 
Table 1.

Interlocutory analysis of a disagreement between two children

\begin{tabular}{|c|c|c|c|c|}
\hline Sequential verbal exchanges & Illocutory speech acts & Occurrence & Vanessa & Audrey \\
\hline \multicolumn{5}{|l|}{$(\ldots)$} \\
\hline \multicolumn{5}{|l|}{ 10: (they lift up w) } \\
\hline 11Va: on the green $(\mathrm{g})$ & Directive- commissive & Proposition & $\mathrm{B}(-,-, \mathrm{w}, \mathrm{g})$ & \\
\hline 12Au: on the brown (b) & Directive- commissive & Proposition & & $\mathrm{A}(-,-, \mathrm{w}, \mathrm{b})$ \\
\hline 13Va $\mathbf{a}_{1}$ : no & Assertive & Rejection of $12 \mathrm{Au}$ & & \\
\hline $13 \mathrm{Va}_{2}$ : on the green & Directive- commissive & Repetition & $\mathrm{B}(-,-, \mathrm{w}, \mathrm{g})$ & \\
\hline $14 \mathrm{Au}_{1:}$ no & Assertive & $\begin{array}{l}\text { Rejection of } \\
13 \mathrm{Va}\end{array}$ & & $\neg \mathrm{B}(-,-,, \mathrm{w}, \mathrm{g})$ \\
\hline $\begin{array}{l}14 \mathrm{Au}_{2} \text { : Let's put the pink one }(\mathrm{p}) \\
\text { there }\end{array}$ & Assertive & Argument & & $\mathrm{B}(-,-, \mathrm{p}, \mathrm{g})$ \\
\hline 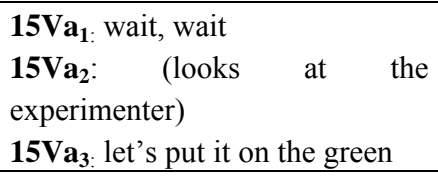 & Directive- commissive & $\begin{array}{l}\text { Request } \\
\text { Repetition } \\
\end{array}$ & $\mathrm{B}(-,-, \mathrm{w}, \mathrm{g})$ & \\
\hline 16Au $\mathbf{A u}_{1:}$ no & Assertive & Rejection of $12 \mathrm{Au}$ & & $\neg \mathrm{B}(-,-, \mathrm{w}, \mathrm{g})$ \\
\hline $\begin{array}{l}16 \mathrm{Au}_{2} \text { : afterwards, let's put that } \\
\text { one there (p on } g \text { using her hand } \\
\text { gesture) }\end{array}$ & Assertive & $\begin{array}{l}\text { Reminder of the } \\
\text { justification of the } \\
\text { rejection }\end{array}$ & & $\mathrm{B}(-,-, \mathrm{p}, \mathrm{g})$ \\
\hline $\begin{array}{l}17 \mathbf{V a}_{1} \text { : yes } \\
17 \mathbf{V a}_{2} \text { : but we must build the } \\
\text { tower there (peg C) }\end{array}$ & $\begin{array}{l}\text { Assertive } \\
\text { Assertive }\end{array}$ & Argument & $\mathrm{C}(-,-,-,-)$, & \\
\hline $\begin{array}{l}\text { 17Va } \\
\text { 17: ah yes } \\
\mathbf{V a}_{\mathbf{4}} \text { : that's it }\end{array}$ & $\begin{array}{l}\text { Expressive } \\
\text { Assertive } \\
\end{array}$ & Agreement & $\begin{array}{l}\neg \mathrm{B}(-,,-, \mathrm{w}, \mathrm{g})+ \\
\mathrm{B}(-,-, \mathrm{p}, \mathrm{g})= \\
\mathrm{C}(-,-,,-,-)\end{array}$ & \\
\hline 18: (co- action) & & $\begin{array}{l}\text { Success and } \\
\text { satisfaction of } 12 \mathrm{Au}\end{array}$ & & \\
\hline \multicolumn{5}{|l|}{ 19: (co- action) } \\
\hline 20Va: OK & Expressive & Agreement & & \\
\hline $\begin{array}{l}\text { 21Va: (smiles) } \\
\text { (...) }\end{array}$ & Expressive & Satisfaction & & \\
\hline
\end{tabular}

